\title{
Italy threatens to disrupt three key European research institutions
}

Italy has drafted a career diplomat to its Ministry of Science expressly to improve its position in European research organisations. Robert Walgate reports from Rome.

ITALY was last week preparing to "dissociate" itself from CERN, the European organisation for nuclear research; to block (for a second year) the budget of the European Space Agency; and to refuse to fund JET, the Joint European Torus for fusion research under construction at Culham, England, for a further four-year term.

The three questions were to be raised at meetings of the council of ESA on 18 December, CERN on 19 December, and the Council of Research Ministers of the EEC on 20 December. So Vito Scalia, Italy's Minister for Scientific Research, told Nature in an exclusive interview last week.

At CERN, said Scalia, Italy would "consider very seriously" adopting merely an observer status if the appointment of a new director-general were not postponed until April, and if there was not "satisfactory clarifaction of the future programme of CERN".

Italy is undoubtedly the most concerned of all countries at Germany's precise intentions towards CERN, since it emerged that Germany may build a 6-km electronposition accelerator - HERA - at Hamburg. HERA is felt by some to be a competitor for CERN, which hopes to build a similar (but bigger) ring in the 1990 s - LEP. Germany denies that LEP and HERA are competitive (see Nature 6 December p 546).

But since Germany pays the ceiling of $25 \%$ of the CERN budget, and CERN costs and salaries are high, it would arguably be cheaper for Germany to build its own LEP on home territory; hence Italy claims its fears may not be groundless.

Italy's view is also complicated by the fact that of the two principal candidates for the director-generalship of CERN one is the German director of the laboratory where HERA may be built - Professor $\mathrm{H}$. Schopper - and the other is the leading Italian physicist Professor A Zichichi. Schopper's appointment at CERN "would be rather like the entry of a Trojan horse", said one Italian official. "Someone should be appointed whose Europeanism is not in question".

In contrast to this view, however, Professor Schopper has always insisted that his laboratory at Hamburg be considered an international institution. At PETRA, presently its largest accelerator and a world leader, he refused to admit groups composed of one nationality. This at one stage excluded Italy, which wanted to run a massive prestige single nation experiment at PETRA. At present there is no Italian group at PETRA, despite the fact that less than half PETRA's experimenters are German. GermanItalian relations are thus somewhat tender on this issue.

At the European Space Agency, Italy will re-affirm its year-old decision to block the ESA budget because, says Scalia, "there is insufficient industrial return to compensate for our $£ 10$ million losses over two years on Spacelab". Here Italy believes that ESA's professed policy of distributing contracts among members in proportion to their contributions is manifestly not working. "Germany underwrote Spacelab $54 \%$, Italy $18 \%$ ", said a ministry spokesman. "But Germany got $62 \%$ of the contractors, ourselves 10\%""

Scalia also criticised France and Germany for failing to contribute to 'L-sat', ESA's venture in Europe-wide television transmission. France and Germany are bi-laterally developing the equivalent 'TV-sat', leaving Britain, Italy, and five other countries alone in the ESA project.

Italy is also interested in re-organising ESA when the present director Roy Gibson completes his term. "The programme lacks momentum and imagination" said an of ficial. According to Scalia, ESA "should find a strong manager".

In Brussels, Italy would like to link the future of the European nuclear fusion experiment, JET, with that of 'Super Sara' - an experiment on the core 'melt-down' of thermal reactors which would take place at the European Commission's joint research centre at Ispra, north Italy. Britain and other delegations have consistently refused to fund the $£ 35$ million experiment, ostensibly because they feel that the costs are too high.

"It would be interesting to know" said Scalia "in what way the countries that oppose such an important programme on reactor safety - one which has been described by America as of great significance - will justify their position to the public ...."

Germany, an Italian official told Nature, had already approached Italy to see if the experiment could be undertaken "Whoever can develop a demonstrably safe reactor, will take the world market" said the of ficial. But ltaly would prefer that the experiment be undertaken under a panEuropean banner.

Criticism of Super Sara has centred on the efficiency of Ispra staff. "We reject that" said the official. Encouraged by the government, Italian unions had sent bi-laterally. Japan has also shown interest. observers to Ispra, to Brussels, and to Culham where JET is being built, "to assess absenteeism, times of arrival for work and so on". The results put Ispra ahead of Culham, and firmly ahead of Brussels, he said.

"We must have a European programme on nuclear safety" said Scalia. "And at Ispra we have a most important establishment both in the quality of its staff and its equipment." JET and Super Sara, he said, "must either stand or fall together".

Italy appears to be strengthening its stand on European scientific and technological issues. With the change of government four months ago a career diplomat was appointed to the Ministry of Scientific Research as 'chief of cabinet' the principal advisor to the new minister and he has been playing an active role in asserting Italy's position in Europe.

The objectives of this exercise may not be entirely a matter of supporting Italy's scientists. The country has taken a strong interest in the industrial aspects of space, having recently announced a $£ 125$ million five-year national programme ("fully complementary to ESA's"), and is mindful of the possible applications of the superconducting technology that will be needed in the long term for high energy accelerators. The proof of nuclear safety is related both to sales of reactors and to convincing Italy's public that nuclear power is acceptable.

"Advanced technology" said Scalia "must be a European problem".

\section{Call for European environment charter}

EUROPE'S environment ministers should convene a conference on the environment some time during Italy's forthcoming presidency of the Council of Ministres, Italy announced at a council meeting at Brussels on Monday. The meeting would demonstrate to environmental groups that governments were prepared to tackle environmental problems, said Italy's science minister Vito Scalia last week.

There should also be agreement on a charter announcing the principle of "polluter pays" said the minister, and ultimately, "no pollution".

However, Italy's own record on pollution control is not outstanding. The United Nations Regional Seas Programme, a component of the UN Environmental Programme, recently advised Italy to lower its standards for pollution of bathing beaches - because the existing standards were impossibly high. "If Italy applied them, all their beaches would be closed" said a UNEP spokesman. "Better to take a realistic level, and then actually apply it." 